
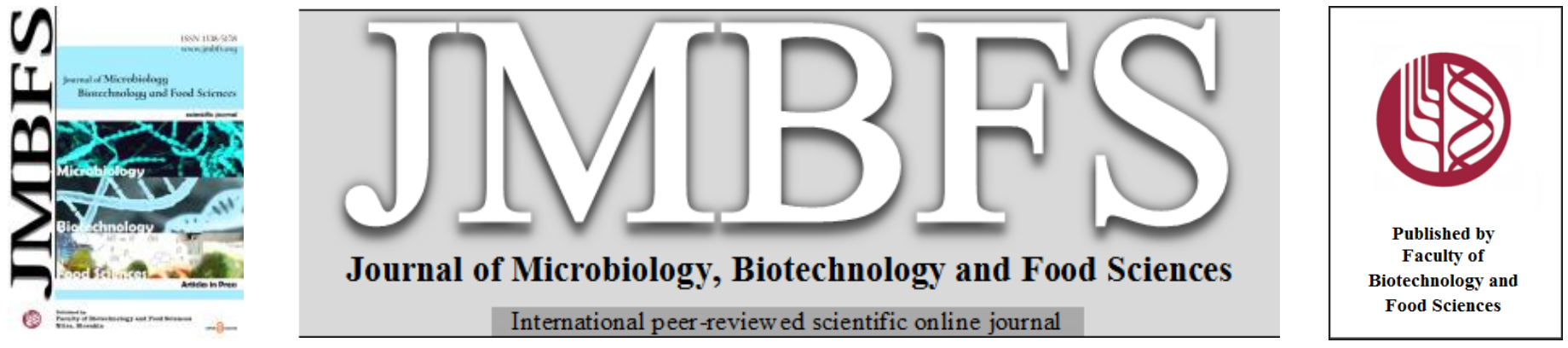

\title{
THE ANTIMUTAGENIC EFFECT OF MULTIFLORAL HONEY IN SALMONELLA/ MICROSOMAL ASSAY AND ITS CORRELATION WITH THE TOTAL POLYPHENOLIC CONTENT
}

\author{
Mabrouka BOUACHA ${ }^{\text {l,*, Ines BOUDIAR }}{ }^{2}$, Akila ABDI ${ }^{2}$, Mohammad Abdulraheem Al-KAFAWEEN ${ }^{3}$ and Messaouda KHALLEF \\ Address(es): Mabrouka BOUACHA \\ ${ }^{1}$ Laboratory of Biochemistry and Environmental Toxicology, Department of Biochemistry, Faculty of Sciences, University of Badji Mokhtar, Annaba, Algeria.
}

${ }^{2}$ Laboratory of Biochemistry and Microbiology, Department of Biochemistry, Faculty of Sciences, University of Badji Mokhtar, Annaba, Algeria.

${ }^{3}$ Faculty of Pharmacy, Department of Pharmacy, Al-Zaytoonah University of Jordan, Amman, Jordan

${ }^{4}$ Department of Biology, Faculty of Natural Sciences, Life Sciences, Earth and the Universe, university of 8 Mai 1945, Guelma, Algeria

*Corresponding author: mabrouka.bouacha@univ-annaba.dz

https://doi.org/10.55251/jmbfs.5557

\section{ARTICLE INFO}

Received 18. 11. 2021

Revised 22. 1. 2022

Accepted 26. 1. 2022

Published 1. 6. 2022

Regular article

OPEN $\partial_{\text {ACCESS }}$

\section{ABSTRACT}

The objective of this study is to determine the antimutagenic effect of honey and its correlation with the concentration of the total polyphenolic content. Seven honey samples were collected from different regions of Algeria. The total polyphenolic content was determined by Folin-Ciocalteu colorimetric assay. The antimutagenic effect was carried out by the AMES Salmonella/ microsome mutagenicity assay against three known mutagenic substances (4-nitro-o-phenylenediamine, sodium azide, and mitomycin C), using Salmonella typhimurium TA98, TA100, and TA102 strains.

The results obtained revealed that Algerian honey contains high polyphenol content, which varied significantly between 38.04 and 286.28 $\mu \mathrm{g}$ of GAE/100 mg of honey. This variation is due to their different botanical and regional origins. In addition, all tested honey exhibited an antimutagenic effect against mutagenic substances; honey is effective to inhibit between $29.18 \pm 11.11 \%$ and $73.14 \pm 11.14 \%$ of mutagenic activity of chemical substances. There is a strong positive correlation between the total polyphenolic content and the antimutagenic proprieties of honey against the mutagenic substances.

The results obtained suggest that honey is effective as an antimutagenic agent; it can play an important role in the protection of the mutagenic effect of DNA caused by chemical substances.

Keywords: AMES assay, antimutagenic effect, honey, phenolic content, Salmonella typhimurium

\section{INTRODUCTION}

Honey is a natural product containing several nutritional and therapeutic properties that are gained from the nectar of flowers (Nikhat and Fazil, 2021; Al-kafaween et al., 2021). It has been used since ancient times as a flavorful sweetener and it is considered a part of traditional medicine (Wang, Andrae and Engeseth, 2002; Alotibi et $\boldsymbol{a l} ., \mathbf{2 0 1 8}$ ). It consists of a highly concentrated solution of a complex mixture of sugar and other constituents, such as minerals, proteins, vitamins, organic acids, flavonoids, phenolic acids, enzymes, and volatile compounds (Alvarez-Suarez et $\boldsymbol{a l . , ~ 2 0 0 9 ;}$; Sachdev, Kumar and Ansari, 2021).

Honey presents a wide range of biological effects such as antimicrobial (Bouacha, et al., 2018; Bouacha and Benbouzid, 2020), wound healing (Alvarez-Suarez et al., 2014; Febriyenti et al., 2019), antioxidant (Ahmed et al., 2018; Erejuwa et al., 2012), anti-inflammatory (Liao et $\boldsymbol{a l} .$, 2018), gastroprotective (Djebli et $\boldsymbol{a l}$. 2021), and anticancer properties (Abbas et $\boldsymbol{a l}$., 2021). However, the quality of honey depends strongly on the source of nectar, plant compounds, geographical region, seasonal and environmental factors, and storage conditions (Ahmed et $\boldsymbol{a l}$., 2018; Matzen et al., 2018)

The compounds that are responsible for the major biological effects of honey are the total polyphenolic content (Gómez-Maqueo et al., 2018; Rodrigues da Silva, Campos Chisté and Fernandes, 2021). Recently, the total polyphenolic content in diet has received increasing attention due to some interesting discoveries about their therapeutic properties (Becerril-Sánchez et al., 2021; Celeiro et al., 2021; González-Ceballos et $\boldsymbol{a l}$, , 2021). Indeed, the total polyphenol content such as phenolic acids, naphthoquinones, xanthones, stilbenes, flavonoids, lignans, lignins, and condensed tannins have become more and more important for scientists who are searching for novel compounds capable to prevent several human diseases, including cancer diseases. This is due to their antimutagenic and anticarcinogenic proprieties (Belščak-Cvitanović et al., 2018; Gómez-Maqueo et al., 2018; Santos-Buelga et al., 2019).
Many mutagenic agents are known as direct-acting mutagens, such as sodium azide $\left(\mathrm{NaN}_{3}\right)$, which directly affect genetic material that can cause point mutation in the genome and structural damage. The 4-nitro- $o$-phenylenediamine can indirectly act on DNA via the induction of the synthesis of different chemicals which can affect DNA directly and causes frameshift mutations (Słoczyńska et al., 2014) Mitomycin C, an antibiotic used in therapy against many forms of human cancer, can interact with biological molecules and can induce genetic hazards in non-tumor cells (Hammarsten et al., 2021). One of the possible approaches to protect DNA from damage caused by mutagen agents is to use natural antimutagenic products that can counteract the effects of mutagenic substances. Hence, searching and identification of antimutagenic and anticarcinogenic components represent a rapidly expanding field of cancer research (Sloczyńska et al., 2014).

Algeria, found in the northern region of the African continent, exhibits highly diversified forest ecosystems and a significant variation in climate that varies from the Mediterranean to the Saharan type. These conditions offer diverse types of high-quality honey that are rich in phytochemical bioactive compounds. Up to date, very few studies have been conducted to investigate the proprieties and application of Algerian honey in human diseases. Indeed, to the best of our knowledge, this is the first study that reports the antimutagenic effect of honey and its relationship with the total polyphenolic content. Therefore, we sought to determine the antimutagenic effect and the possible preventive capacity of honey from seven different floral and geographic sources of Algeria against the mutagenicity of three positive mutagens:4-nitro-o-phenylenediamine, sodium azide, and mitomycin $\mathrm{C}$, and its relationship with the total polyphenolic content of honey. 


\section{MATERIAL AND METHODS}

Honey samples

Seven Algerian multifloral honey samples from Apis mellifera were obtained directly from beekeepers from different geographical regions and vegetation sources (Table 1). Honey samples were collected in a sterile container and kept at $4{ }^{\circ} \mathrm{C}$ in darkness until usage. The botanical origin of the honey samples was directly related to the type of plants that the honeybee gleaned. Honey samples were collected in a sterile Erlenmeyer flask and the samples were stored at room temperature and were hidden from the light exposure until usage.

\begin{tabular}{|c|c|c|c|}
\hline Honey samples & Floral source & City & Geographical region \\
\hline 1 & Eucalyptus, Pinus & El Taref & Extreme north-eastern of Algeria \\
\hline 2 & Quercus, Castanea & Jijel & North-eastern of Algeria \\
\hline 3 & $\begin{array}{l}\text { Citrus: C.maxima, C. sinensis, } \\
\text { C. aurantifolia, C. limon }\end{array}$ & El Blida & The central part of the north of Algeria \\
\hline 4 & Thymus hirtus, Marrubium vulgare & M'Sila & The central part of the north of Algeria \\
\hline 5 & Ziziphus, Artemisia, & Djelfa & Central partof north of Algeria \\
\hline 6 & Ruta graviolens, Pituranthos scoparius, & Batna & East of Algeria \\
\hline 7 & $\begin{array}{l}\text { Rosmarinus officinalis, Ecballium elaterium, } \\
\text { Lonicera caprifolium }\end{array}$ & Tebessa & East of Algeria \\
\hline
\end{tabular}

\section{Tester strains}

The Salmonella typhimurium tester strains used in AMES assay were unable to grow in the absence of histidine because each tester strain contains a differen mutation in various genes in the histidine operon; this makes the tester strain unable to synthesize this amino acid. The tester strain Salmonella typhimurium TA98 was used to detect mutagenic substances causing frameshift mutations. However, TA100 was used to detect mutagens causing base-pair substitutions mutations and TA102 was used to detect mutagens causing transition/transversion mutations (Mortelmans and Zeiger, 2000; Tarawneh et al., 2021; Al-Bakri et al., 2019; Huwaitat et al., 2021).

\section{Determination of total polyphenolic content}

The determination of total phenolic content was performed using the FolinCiocalteu method (Deng et $\boldsymbol{a l . , 2 0 1 8}$ ), and the results were expressed as $\mu \mathrm{g}$ gallic $\mathrm{acid} / \mathrm{mg}$ of honey. Initially, $0.5 \mathrm{~mL}$ of honey solution was mixed with $0.3 \mathrm{~mL}$ of the Folin-Ciocalteu reagent and $2 \mathrm{~mL}$ of a $15 \%$ sodium carbonate solution Distilled water was added to a final volume of $5 \mathrm{~mL}$. All samples were incubated at room temperature in the dark conditions for 2 hours, and their optical density was read at $760 \mathrm{~nm}$ against a blank of distilled water. A standard curve of gallic acid was drawn within a concentration range of $7.0 \times 10^{-4}$ to $7.8 \times 10^{-3} \mathrm{mg} / \mathrm{mL}$. The linearity obtained was 0.982 (Chaiyasut et al., 2018).

\section{Antimutagenic effect}

The antimutagenic effect of honey was achieved according to the lightly modified assay described previously by Mortelmans et Zeiger, (2000). This assay evaluates the ability of a chemical or a physical agent to cause specific mutations in different strains of Salmonella typhimurium. These strains are carrying a specific mutation in one of the genes encoding the synthesis of histidine. This mutation makes the bacteria unable to grow on a medium without histidine (His $\left.{ }^{-}\right)$. By exposing the His bacteria to mutagenic agents; the histidine ( $\left.\mathrm{His}^{-}\right)$mutations reverse to His ${ }^{+}$.

In this study, three strains of Salmonella typhimurium with three positive mutagens were used: 4-nitro-o-phenylenediamine for S. typhimurium 98, sodium azide for S. typhimurium 100, and mitomycin C for S. typhimurium 102 . The presence of genetic markers and the plasmids (pKM101 and pAQ1) has been systematically checked.

Each bacterium was cultured in $20 \mathrm{~mL}$ of nutrient broth and incubated for $24 \mathrm{~h}$ at $37{ }^{\circ} \mathrm{C}$ with continuous agitation. $100 \mu \mathrm{L}$ of overnight culture, $100 \mu \mathrm{L}$ of each honey, and $100 \mu \mathrm{L}$ of positive mutagen are mixed with $500 \mu \mathrm{L}$ of phosphate buffer (13.8 $\mathrm{g} / \mathrm{L} \mathrm{NaH} \mathrm{PO}_{4}$ and $14.2 \mathrm{~g} / \mathrm{L} \mathrm{Na}_{2} \mathrm{HPO}_{4}$ ). The mixture is pre-incubated at $37^{\circ} \mathrm{C}$ for 20 minutes.

A volume of $2 \mathrm{~mL}$ of molten soft agar medium with histidine and biotin solution was added aseptically to the mixture and poured after slight agitation into a minimal glucose agar plate. After solidification of the mixture, the plates are incubated for 48 hours, at $37^{\circ} \mathrm{C}$. The number of revertant colonies on the plates was counted after incubation (Mortelmans and Zeiger, 2000; Al-kafawenn et al., 2021).

Honey is considered to have a mutagenic effect if the reversion coefficient (RC) is greater than or equal to two. This coefficient is calculated according to this formula: $R C=\frac{R 1}{R 0}$

The antimutagenic effect of honey is expressed as a percentage of inhibition (I \%) of mutagenicity of chemical substances, it is calculated according to the following formula: $I(\%)=100-\left(\frac{R 3}{R 2} \times 100\right)$

Where: $\mathrm{R}_{0}$ is the number of spontaneous revertant colonies per plate

$R_{1}$ is the number of revertant colonies induced by honey

$R_{2}$ is the number of revertant colonies per plate exposed to positive mutagen

$\mathrm{R}_{3}$ is the number of revertant colonies per plate exposed to positive mutagen and honey.

\section{Statistical analysis}

Significant differences were calculated using analysis of variance (ANOVA) followed by a multiple ranges test (Tukey). Correlations between the antimutagenic effect of honey and total polyphenolic content were obtained using correlation coefficient $(r)$. All analyses were carried out using the software GraphPad Prism version 7.00 (Graph Pad Software, Inc., La Jola, CA, USA).

\section{RESULTS AND DISCUSSION}

\section{Determination of total polyphenolic content}

The total phenolic content of Algerian honey represented (Figure 1) was found to vary significantly, between 38.04 and $286.28 \mu \mathrm{g}$ of GAE/100g of honey. This range is similar to the ranges typically found for European (Kuś et al., 2014) and African honey samples (Beretta et al., 2005). While, these values are also considered relatively high in comparison with those found in other regions in Algeria (14.50 to $99.62 \mu \mathrm{g}$ of GAE / $100 \mathrm{mg}$ ) or other countries such as Brazil (26.00 to $100.00 \mu \mathrm{g}$ of GAE/100 mg of honey) (Nascimento et al., 2018; Zerrouk et al., 2018). Ciappini and Stoppani (2014) reported that the total polyphenolic content in Argentinean honey varied from 40.30 to $193.00 \mu \mathrm{g}$ of GAE /100 mg of honey. Indeed, the floral source and geographical region of honey samples mainly influence the type and concentration of polyphenolic content; these findings are in agreement with results reported previously (Al et al., 2009; Ciappini and Stoppani, 2014; Cianciosi et al., 2018; Cheung et al., 2019).

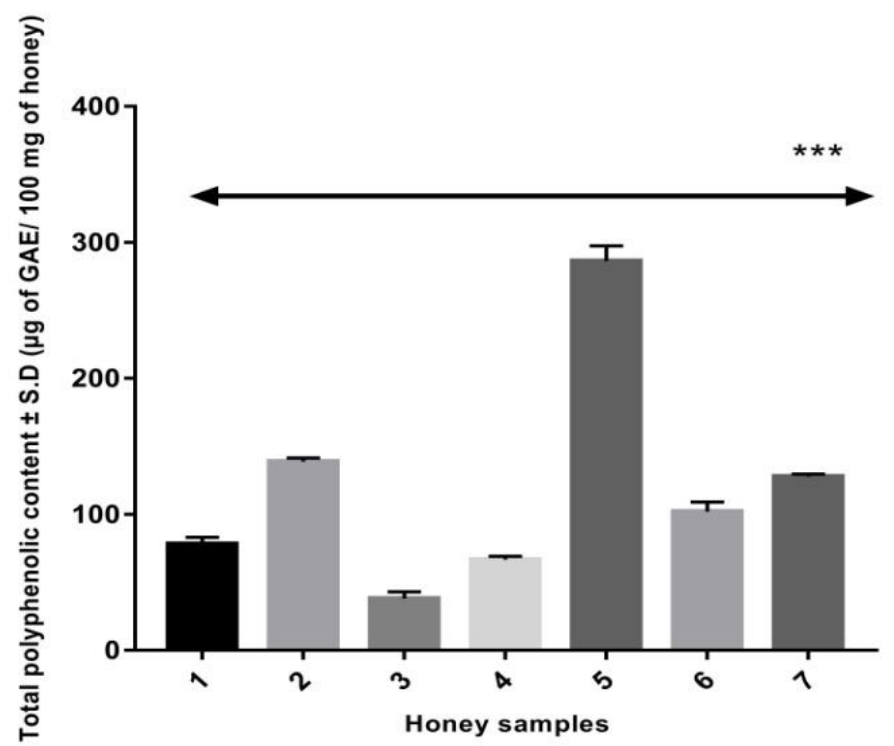

Figure 1 Concentration of total polyphenolic content in honey ( $\mu \mathrm{g}$ of GAE/100 $\mathrm{mg}$ of honey), calculated as the mean of three repeated experiments $\pm \mathrm{SD}$. ***: means that there are very highly significant differences between the tota polyphenolic content of honey samples at $P<0.0001$

\section{Mutagenic and antimutagenic effect of honey}

As shown in Table 2, none of the honey samples showed a mutagenic effect, hence honey is considered as a non-mutagenic product. However, all honey samples have displayed a significant antimutagenic effect against the three positive mutagens. 
The percentage of antimutagenicity is ranged from $29.18 \pm 11.11$ to $73.14 \pm 11.14 \%$. Honey is more effective to reduce the number of revertant colonies in S.typhimurium TA98 and TA100 than in strain TA102, and this can be explained by the type of mutations. Since strains TA98 and TA100 are known to detect frameshift and base-pair substitution mutation types, respectively, strain TA102 is known to detect transition/transversion mutation types. In addition, the results showed that honey samples 5 and sample 2 can reduce the highest percentage of revertant colonies on the three tested strains. These results are in concordance with those of Saxena et al. (2012); reported that honey exhibits highly inhibition of mutations caused by ethyl methanesulfonate, ultraviolet, and gamma radiation in S.typhimurium TA100 and TA102. Honey is effective to reduce the mutagenicity induced by 4-Nitro- $o$-phenylenediamine, sodium azide, and mitomycin. There are highly significant differences among the antimutagenic effects of honey
$(P<0.0001)$. It appears that honey has more antimutagenic effect in S. typhimurium TA98 and TA100 strains than in $S$. typhimurium TA102 strain; this is probably related to the tester strains and to the differences in mechanistic pathways of the antimutagenic effects of honey. The percentage of inhibition of mutagenicity varied from 26.18 to $73.14 \%$. This range is comparable to the range found by Saxena et al. (2012) which is between 3 and $77 \%$. Indeed, honey was found to be highly effective to inhibit frameshift and base-pair substitution mutation types than transition/transversion mutation types. Very few studies were reported regarding the potential antimutagenic effects of honey in bacterial strains; however, Wang et al. (2002) have reported that floral honey from the USA exhibits antimutagenicity against Trp-p-1, a heterocyclic food mutagen in Ames Assay.

Table 2 Mutagenic and antimutagenic effect of seven honey on Salmonella/microsomal assay represented as a revertant coefficient $(\mathrm{RC} \pm \mathrm{SD})$ and percentage of inhibition of mutagenicity ( $\mathrm{I} \pm \mathrm{SD} \%)$, respectively.

\begin{tabular}{lcccccc}
\hline \multirow{2}{*}{ Honey samples } & \multicolumn{2}{c}{ S. typhimurium TA98 } & \multicolumn{2}{c}{ S. typhimurium TA100 } & \multicolumn{1}{c}{ S. typhimurium TA102 } \\
\cline { 2 - 7 } & $\mathrm{RC} \pm \mathrm{SD}$ & $\mathrm{I} \pm \mathrm{SD} \%$ & $\mathrm{RC} \pm \mathrm{SD}$ & $\mathrm{I} \pm \mathrm{SD} \%$ & $\mathrm{RC} \pm \mathrm{SD}$ & $\mathrm{I} \pm \mathrm{SD} \%$ \\
1 & $1.10 \pm 0.11$ & $50.45 \pm 07.14^{\mathrm{a}}$ & $1.21 \pm 0.28$ & $49,65 \pm 07.91^{\mathrm{a}}$ & $1.23 \pm 0.02$ & $29.18 \pm 11.11^{\mathrm{a}}$ \\
2 & $1.09 \pm 0.25$ & $62.26 \pm 14.11^{\mathrm{b}}$ & $1.23 \pm 0.09$ & $52,81 \pm 11.32^{\mathrm{a}}$ & $1.17 \pm 0.07$ & $36.43 \pm 06.34^{\mathrm{b}}$ \\
3 & $1.14 \pm 0.31$ & $49.24 \pm 09.62^{\mathrm{a}}$ & $1.08 \pm 0.49$ & $44.14 \pm 12.12^{\mathrm{b}}$ & $1.18 \pm 0.18$ & $26.18 \pm 09.78^{\mathrm{a}}$ \\
4 & $1.21 \pm 0.27$ & $53.17 \pm 12.84^{\mathrm{a}}$ & $1.27 \pm 0.45$ & $50.81 \pm 06.85^{\mathrm{a}}$ & $1.22 \pm 0.27$ & $27.12 \pm 12.04^{\mathrm{a}}$ \\
5 & $1.07 \pm 0.39$ & $73.14 \pm 11.14^{\mathrm{c}}$ & $1.15 \pm 0.12$ & $68.61 \pm 14.79^{\mathrm{c}}$ & $1.13 \pm 0.19$ & $38.44 \pm 08.12^{\mathrm{c}}$ \\
6 & $1.32 \pm 0.28$ & $59.43 \pm 7.28^{\mathrm{b}}$ & $1.19 \pm 0.32$ & $53.01 \pm 09.43$ & $1.14 \pm 0.32$ & $26.52 \pm 11.67^{\mathrm{a}}$ \\
7 & $1.07 \pm 0.13$ & $57.54 \pm 05.12^{\mathrm{b}}$ & $1.12 \pm 0.28$ & $57.25 \pm 04.78^{\mathrm{d}}$ & $1.25 \pm 0.10$ & $32.32 \pm 12.11^{\mathrm{b}}$ \\
\hline
\end{tabular}

Correlation between antimutagenic effect and total polyphenolic content

There is a strong positive correlation between total polyphenolic content and the efficiency of honey to inhibit the mutagenicity of 4-nitro-o-phenylenediamine, sodium azide, and mitomycin C (Figure 2). The correlation coefficient is ranged between 0.806 and 0.938 , it was found in decreasing order as follows TA100>TA98>TA102. It is known that honey contains several bioactive substances others that total polyphenolic content such as sugar, vitamins, trace elements, amino acids, proteins and carotenes, organic acids as well as certain enzymes including glucose oxidase, invertase, and catalase (Erejuwa, Sulaiman and Ab Wahab, 2012); which may contribute in the antimutagenic properties of honey. Indeed, honey has a protective effect against mutagenic substances. These

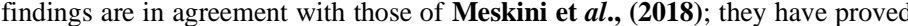
that the topical application of honey inhibits the carcinogenic effects of 7,12 Dimethylbenz(a)anthracene- on mice skin. In addition, the results reported by Fauzi et al, (2011); showed that Tualang Honey has a significant anticancer activity, which induces apoptosis and disrupts the mitochondrial membrane potential of human breast and cervical cancer cell lines.

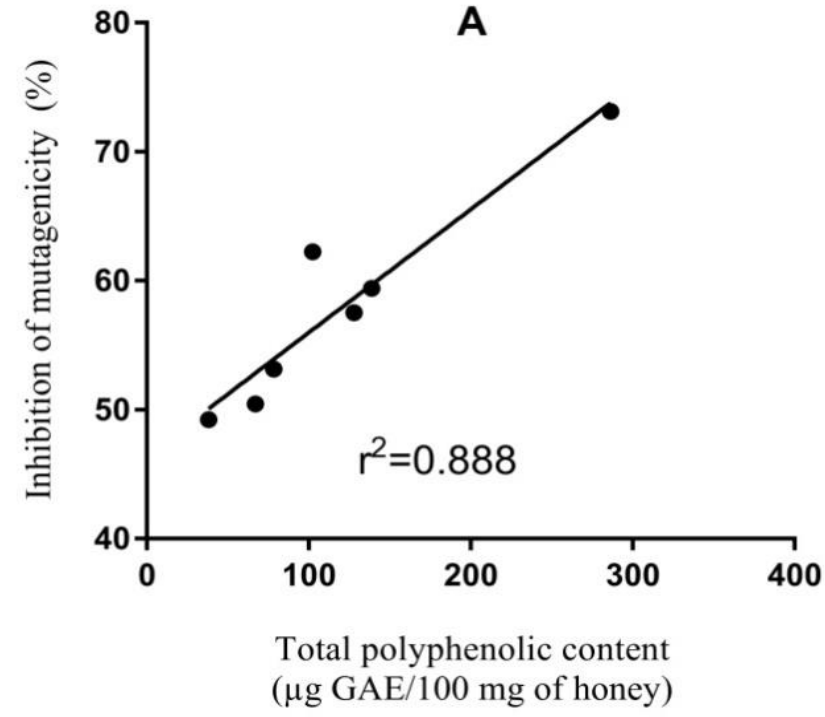

( $\mu \mathrm{g}$ GAE/100 mg of honey)

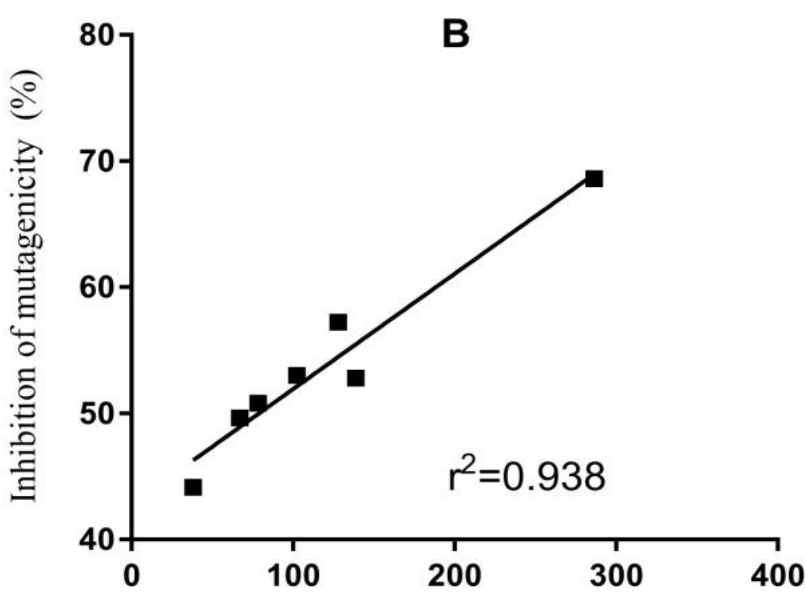

Total polyphenolic content ( $\mu \mathrm{g}$ GAE/ $100 \mathrm{mg}$ of honey)

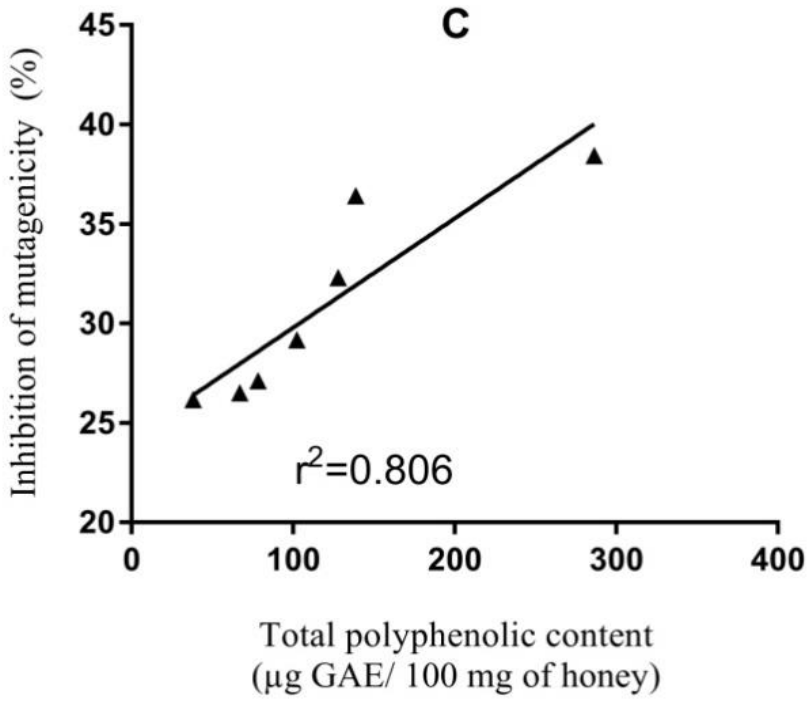

Figure 2 Correlation between the concentration of total polyphenolic content in honey and the inhibition of the mutagenic effect of chemical substances in Salmonella typhimurium TA98 (A), Salmonella typhimurium TA100 (B), and in Salmonella typhimurium TA102 (C). $\mathrm{r}^{2}$ : is the $\mathrm{r}$ square of the coefficient of correlation 
The antimutagenic effect of total polyphenolic content of natural compounds such as plant extracts and vegetable food extracts was previously described by others authors (de Mejía, Castaño-Tostado and Loarca-Piña, 1999; Słoczyńska et al. 2014; Delgado-Vargas et $\boldsymbol{a l}$., 2018; Temviriyanukul et $\boldsymbol{a l}$., 2021). However, the mechanisms and the types of active compounds involved in the protective effects of plants against DNA mutations have not been clearly identified. Whereas, reduction of oxidative stress is the main factor in the prevention of DNA mutations and in the decrease of chronic disease risk, including some forms of cancer (Makhafola et al., 2016; Tarawneh et al., 2021; Al-Bakri et al., 2019; Huwaita et al., 2021). Moreover, the antimutagenic effect of honey may be attributed to different mechanisms, including cell cycle arrest, activation of mitochondrial pathway, induction of mitochondrial outer membrane permeabilization, induction of apoptosis, modulation of oxidative stress, amelioration of inflammation, modulation of insulin signaling, and inhibition of angiogenesis in cancer cells (Erejuwa et $\boldsymbol{a l . , 2 0 1 4}$ ). These findings are in agreement with those of Cianciosi et $\boldsymbol{a l}$. (2018) and Miguel et $\boldsymbol{a l}$. (2017); they declared that the phenolic compounds are associated with health benefits of honey; ranging from antioxidant, immunomodulatory, and anti-inflammatory activity to anticancer effects (Abbas et $\boldsymbol{a l . , 2 0 2 1}$ ). On another hand, we suggest in this study that the concentration of total polyphenolic content is an important indicator in the choice of honey of good quality since it correlates positively with the antimutagenic effect of honey.

\section{CONCLUSION}

In conclusion, we reported in this study that honey may act to decrease the incidence of DNA mutations; this is correlated with the phytochemical compounds in honey, particularly, the total polyphenolic content. Indeed, there is a strong correlation between the antimutagenic effect of honey and its composition with total polyphenolic content.

In addition, we suggest in this study that honey may contribute as an alternative to pharmaceutical medications that can prevent and inhibit the DNA mutations responsible for serious human diseases, including cancer. However, further research on the pathway and mechanism of action of honey in the reduction of DNA mutations is highly recommended.

Conflict of interest: We declare that we have no conflict of interest.

\section{REFERENCES}

Abbas, M., Shah, I., Nawaz, M. A., Pervez, S., Hussain, Y., Niaz, K., \& Khan, F. (2021). Honey Against Cancer. In Nutraceuticals and Cancer Signaling, Springer pp: 401-418. ). http://dx.doi.org/10.1007/978-3-030-74035-1_15

Ahmed, S., Sulaiman, S. A., Baig, A. A., Ibrahim, M., Liaqat, S., Fatima, S., and Othman, N. H. (2018). Honey as a potential natural antioxidant medicine: an insight into its molecular mechanisms of action. Oxidative medicine and cellular longevity, 2018. http://dx.doi.org/10.1155/2018/8367846

Al, M. L., Daniel, D., Moise, A., Bobis, O., Laslo, L., and Bogdanov, S. (2009). Physico-chemical and bioactive properties of different floral origin honeys from $\begin{array}{llll}\text { Romania. Food } & \text { chemistry, }\end{array}$ http://dx.doi.org/110.1016/j.foodchem.2008.06.055

Al-Bakri, A.G. and Mahmoud, N.N., 2019. Photothermal-induced antibacterial activity of gold nanorods loaded into polymeric hydrogel against Pseudomonas $\begin{array}{llll}\text { aeruginosa } & \text { biofilm. } & \text { Molecules, }\end{array}$ https://doi.org/10.3390/molecules24142661

Alotibi, I. A., Harakeh, S. M., Al-Mamary, M., Mariod, A. A., Al-Jaouni, S. K., Al-Masaud, S., and Al-Hindi, R. R. (2018). Floral markers and biological activity of Saudi honey. Saudi journal of biological sciences, 25(7), 1369-1374. http://dx.doi.org/ 10.1016/j.sjbs.2018.05.0211

Alvarez-Suarez, J. M., Tulipani, S., Romandini, S., Vidal, A., and Battino, M (2009). Methodological aspects about determination of phenolic compounds and in vitro evaluation of antioxidant capacity in the honey: a review. Current Analytical Chemistry, 5(4), 293-302. http://dx.doi.org/10.2174/157341109789077768

Becerril-Sánchez, A. L., Quintero-Salazar, B., Dublán-García, O., and EscalonaBuendía, H. B. (2021). Phenolic Compounds in Honey and Their Relationship with Antioxidant Activity, Botanical Origin, and Color. Antioxidants, 10(11), 1700. http://dx.doi.org/10.3390/antiox10081207

Belščak-Cvitanović, A., Durgo, K., Huđek, A., Bačun-Družina, V., and Komes, D (2018). Overview of polyphenols and their properties. In Polyphenols : Properties, recovery, and applications $\mathrm{Ed}$ : Elsevier, (p. 3-44). http://dx.doi.org/10.1016/B9780-12-813572-3.00001-4

Beretta, G., Granata, P., Ferrero, M., Orioli, M., and Maffei Facino, R. (2005) Standardization of antioxidant properties of honey by a combination of spectrophotometric/fluorimetric assays and chemometrics. Analytica Chimica Acta, 533(2), 185-191. https://dx.doi.org/10.1016/j.aca.2004.11.010

Bouacha, M., Ayed, H., and Grara, N. (2018). Honey Bee as Alternative Medicine to Treat Eleven Multidrug-Resistant Bacteria Causing Urinary Tract Infection $\begin{array}{llll}\text { during Pregnancy. } & \text { Scientia Pharmaceutica, } & 86(2), & 14\end{array}$ https://dx.doi.org/10.3390/scipharm86020014
Bouacha, M., \& Benbouzid, H. (2020). Antibacterial Properties of Honey from Different Algerian Regions against Staphylococcus aureus Strains from Wounds. Journal of Pure and Applied Microbiology, 14(1), 447-453. http://dx.doi.org/10.22207/JPAM.14.1.46

Chaiyasut, C., Kesika, P., Peerajan, S., and Sivamaruthi, B. S. (2018). The total polyphenolic content and antioxidant properties of various honey and sugars. Asian Journal of Pharmaceutical and Clinical Research, 11(5), 467. https://dx.doi.org/10.22159/ajpcr.2018.v11i5.24696

Cheung, Y., Meenu, M., Yu, X., and Xu, B. (2019). Phenolic acids and flavonoids profiles of commercial honey from different floral sources and geographic sources. International Journal of Food Properties, 22(1), 290-308. https://dx.doi.org/10.1080/10942912.2019.1579835

Cianciosi, D., Forbes-Hernández, T. Y., Afrin, S., Gasparrini, M., ReboredoRodriguez, P., Manna, P. P., Zhang, J., Bravo Lamas, L., Martínez Flórez, S. Agudo Toyos, P., Quiles, J. L., Giampieri, F., and Battino, M. (2018). Phenolic Compounds in Honey and Their Associated Health Benefits: A Review. Molecules, 23(9), 2322. https://dx.doi.org/10.3390/molecules 23092322

Ciappini, M. C., and Stoppani, F. S. (2014). Determination of Antioxidant Capacity, Flavonoids, and Total Phenolic Content in Eucalyptus and Clover Honeys. Journal of Apicultural Science, 58(1), 103-111. https://dx.doi.org/10.2478/jas-2014-0010

Delgado-Vargas, F., Sicairos-Medina, L. Y., Luna-Mandujan, A. G., LópezAngulo, G., Salazar-Salas, N. Y., Vega-García, M. O., Heredia, J. B., and LópezValenzuela, J. Á. (2018). Phenolic profiles, antioxidant and antimutagenic activities of Solanum lycopersicum var. Cerasiforme accessions from Mexico. $\begin{array}{lllll}\text { CyTA - Journal of Food, } & \text { 16(1), }\end{array}$ https://dx.doi.org/10.1080/19476337.2018.1481146

de Mejía, E. G., Castaño-Tostado, E., and Loarca-Piña, G. (1999). Antimutagenic effects of natural phenolic compounds in beans. Mutation Research/Genetic Toxicology and Environmental Mutagenesis, 441(1), 1-9. https://dx.doi.org/10.1016/S1383-5718(99)00040-6

Deng, J., Liu, R., Lu, Q., Hao, P., Xu, A., Zhang, J., and Tan, J. (2018). Biochemical properties, antibacterial and cellular antioxidant activities of buckwheat honey in comparison to manuka honey. Food Chemistry, 252, 243-249. https://dx.doi.org/10.1016/j.foodchem.2018.01.115

Djebli, N., Mustafa, M. R., Keskin, M., and Kolayli, S. (2021). Anti-ulcerogenic and cytoprotective effects of Saharian (Sidr) honey from Algeria. Combinatorial Chemistry \& High Throughput Screening, 24(10), 1664-1670. http://dx.doi.org/10.2174/1386207323999201117114008

Erejuwa, O. O., Sulaiman, S. A., and Ab Wahab, M. S. (2012). Honey: A Novel Antioxidant. Molecules, 17(4), 4400-4423. https://dx.doi.org/10.3390/molecules 17044400

Erejuwa, O., Sulaiman, S., and Wahab, M. (2014). Effects of Honey and Its Mechanisms of Action on the Development and Progression of Cancer. Molecules, 19(2), 2497-2522. https://dx.doi.org/10.3390/molecules19022497

Fauzi, A. N., Norazmi, Mohd. N., and Yaacob, N. S. (2011). Tualang honey induces apoptosis and disrupts the mitochondrial membrane potential of human breast and cervical cancer cell lines. Food and Chemical Toxicology, 49(4), 871-878. https://dx.doi.org/10.1016/j.fct.2010.12.010

Febriyenti, F., Lucida, H., Almahdy, A., Alfikriyah, I., and Hanif, M. (2019). Wound-healing effect of honey gel and film. Journal of pharmacy \& bioallied sciences, 11(2), 176. https://dx.doi.org/10.4103/JPBS.JPBS_184_18

Gómez-Maqueo, A., Escobedo-Avellaneda, Z., Cano, M. P., and Welti-Chanes, J. (2018). Phenolic compounds in food. In Phenolic Compounds in Food (p. 33-58). CRC Press. https://dx.doi.org/10.1201/9781315120157-1

González-Ceballos, L., del Mar Cavia, M., Fernández-Muiño, M. A., Osés, S. M., Sancho, M. T., Ibeas, S., García, F. C., García, J. M., and Vallejos, S. (2021). A simple one-pot determination of both total phenolic content and antioxidant activity of honey by polymer chemosensors. Food Chemistry, 342, 128300. https://dx.doi.org./10.1016/j.foodchem.2020.128300

Hammarsten, O., Muslimovic, A., Thunström, S., Ek, T., and Johansson, P. (2021) Use of the cell division assay to diagnose Fanconi anemia patients' hypersensitivity to mitomycin C. Cytometry Part B: Clinical Cytometry, 100(3), 370-376 https://dx.doi.org/10.1002/cyto.b.21950

Huwaitat R, Coulter SM, Porter SL, Pentlavalli S, Laverty G. Antibacterial and antibiofilm efficacy of synthetic polymyxin-mimetic lipopeptides. J Pept Sci. 2021;113(1):24-38.

Kuś, P. M., Congiu, F., Teper, D., Sroka, Z., Jerković, I., and Tuberoso, C. I. G. (2014). Antioxidant activity, color characteristics, total phenol content and general HPLC fingerprints of six Polish unifloral honey types. LWT - Food Science and Technology, 55(1), 124-130. https://dx.doi.org/10.1016/j.1wt.2013.09.016

Liao, J., Li, C., Huang, J., Liu, W., Chen, H., Liao, S., Chen, H., and Rui, W. (2018). Structure characterization of honey-processed Astragalus polysaccharides and its anti-inflammatory activity in vitro. Molecules, 23(1), 168 https://dx.doi.org/10.3390/molecules23010168

Makhafola, T. J., Elgorashi, E. E., McGaw, L. J., Verschaeve, L., and Eloff, J. N. (2016). The correlation between antimutagenic activity and total phenolic content of extracts of 31 plant species with high antioxidant activity. BMC Complementary and Alternative Medicine, 16(1). https://dx.doi.org/10.1186/s12906-016-1437-x 
Matzen, R. D., Zinck Leth-Espensen, J., Jansson, T., Nielsen, D. S., Lund, M. N., and Matzen, S. (2018). The Antibacterial Effect In Vitro of Honey Derived from Various Danish Flora. Dermatology Research and Practice. https://dx.doi.org/10.1155/2018/7021713

Meskini Milani, S., Najafi, M., Alizadeh, P., and Rezazadeh, H. (2018). Inhibitory Effect of Honey on 7,12-Dimethylbenz(a)anthracene- Initiated and Croton OilPromoted Skin Carcinogenesis. Jundishapur Journal of Natural Pharmaceutical Products, In Press(In Press). https://dx.doi.org/10.5812/jjnpp.57992

Miguel, M., Antunes, M., and Faleiro, M. (2017). Honey as a Complementary Medicine. Integrative Medicine Insights, 12, 117863371770286 https://dx.doi.org/10.1177/1178633717702869

Mortelmans, K., and Zeiger, E. (2000). The Ames Salmonella/microsome mutagenicity assay. Mutation Research/Fundamental and Molecular Mechanisms of Mutagenesis, 455(1-2), 29-60. https://dx.doi.org/10.1016/S00275107(00)00064-6

Mohammad A. Al-kafaween, A.B.M.H., Hamid Ali Nagi Al-Jamal., 2021. The Beneficial Effects of Stingless Bee Kelulut Honey Against Pseudomonas aeruginosa and Streptococcus pyogenes Planktonic and Biofilm. Tropical Journal of Natural Product Research, 5(10), 1788-1796.

Nascimento, K. S. do, Gasparotto Sattler, J. A., Lauer Macedo, L. F., Serna González, C. V., Pereira de Melo, I. L., da Silva Araújo, E., Granato, D., Sattler, A., and de Almeida-Muradian, L. B. (2018). Phenolic compounds, antioxidant capacity and physicochemical properties of Brazilian Apis mellifera honeys. $L W T$, 91, 85-94. https://dx.doi.org/10.1016/j.1wt.2018.01.016

Nikhat, S., and\& Fazil, M. (2021). History, phytochemistry, experimental pharmacology and clinical uses of honey: A comprehensive review with special reference to Unani medicine. Journal of Ethnopharmacology, 114614 https://dx.doi.org/10.1016/j.jep.2021.114145

Rodrigues da Silva, L., Campos Chisté, R., and Fernandes, E. (2021). Chemica and Antioxidant Characterization of the Portuguese Heather Honey from Calluna vulgaris. Separations, 8(10), 177. https://dx.doi.org/10.21721/p2p.2021v7n2.p63 87

Sachdev, S., Kumar, A., and Ansari, M. I. (2021). Health Benefit, Traditional, and Modern Uses of Natural Honey. In Non-Timber Forest Products (p. 281-299). Springer. https://dx.doi.org/10.1007/978-3-030-73077-2_12

Santos-Buelga, C., González-Paramás, A. M., Oludemi, T., Ayuda-Durán, B., and González-Manzano, S. (2019). Chapter Four-Plant phenolics as functional food ingredients. In I. C. F. R. Ferreira \& L. Barros (Éds.), Advances in Food and Nutrition Research (Vol. 90, p. 183-257). Academic Press. https://dx.doi.org/10.1016/bs.afnr.2019.02.012

Saxena, S., Gautam, S., Maru, G., Kawle, D., and Sharma, A. (2012). Suppression of error prone pathway is responsible for antimutagenic activity of honey. Food and Chemical Toxicology, 50(3-4), 625-633. https://dx.doi.org/10.1016/j.fct.2012.01.003

Scepankova, H., Pinto, C. A., Paula, V., Estevinho, L. M., and Saraiva, J. A (2021). Conventional and emergent technologies for honey processing: A perspective on microbiological safety, bioactivity, and quality. Comprehensive Reviews in Food Science and Food Safety. https://dx.doi.org/10.1111/j.15414337.2011.00177.x

Słoczyńska, K., Powroźnik, B., Pękala, E., and Waszkielewicz, A. M. (2014). Antimutagenic compounds and their possible mechanisms of action. Journal of Applied Genetics, 55(2), 273-285. https://dx.doi.org/10.1007/s13353-014-0198-9 Tarawneh, O., Alwahsh, W., Abul-Futouh, H., Al-Samad, L.A., Hamadneh, L., Abu Mahfouz, H. and Fadhil Abed, A., 2021. Determination of Antimicrobial and Antibiofilm Activity of Combined LVX and AMP Impregnated in p(HEMA) Hydrogel. Applied Sciences, 11(18), 8345. https://doi.org/10.3390/app11188345 Temviriyanukul, P., Kittibunchakul, S., Trisonthi, P., Inthachat, W., Siriwan, D. and Suttisansanee, U. (2021). Analysis of Phytonutrients, Anti-Mutagenic and Chemopreventive Effects of Tropical Fruit Extracts. Foods, 10(11), 2600. https://dx.doi.org/10.1002/9781118253649.ch1

Wang, X.-H., Andrae, L., \& Engeseth, N. J. (2002). Antimutagenic Effect of Various Honeys and Sugars against Trp-p-1. Journal of Agricultural and Food Chemistry, 50(23), 6923-6928. https://dx.doi.org/10.1021/jf025641

Zerrouk, S., Seijo, M. C., Escuredo, O., and Rodríguez-Flores, M. S. (2018)

Characterization of Ziziphus lotus (jujube) honey produced in Algeria. Journal of Apicultural Research, 57(1), 166-174. https://dx.doi.org/10.1080/00218839.2017.1399663 